\title{
Andi Mannappiang: Raja, Pejuang dan Penegak Hukum, 1905-1962
}

\author{
Narti, Bahri, Mustari Bosra \\ Prodi Pendidikan Sejarah Fakultas Ilmu Sosial Universitas Negeri Makassar \\ narti6062@gmail.com
}

\begin{abstract}
Abstrak
Penelitian ini bertujuan untuk mendeskripsikan tentang Andi Mannappiang: Raja, Pejuang dan penegak hukum (1905-1962) dengan mengungkapkan latar belakang kehidupan, Pendidikan, kiprah dan pemikiran Andi Mannappiang sebagai raja, serta kiprah dan pemikiran Andi Mannappiang sebagai pejuang dan penegak hukum. Dalam penelitian ini menunjukkan bahwa sebelum kemerdekaan Indonesia Bantaeng di bawah tekanan Belanda dan Jepang namun setelah kemerdekaan kondisi sosial-politik di Bantaengsangat kacau karena kedatangan NICA oleh karena itu dibentuklah laskar perjuangan untuk mempertahankan kemerdekaan Republik Indonesia di Bantaeng. Andi Mannappiang merupakan pejuang yang menggerakkan perlawanan di Bantaeng.Dalam penelitian ini menjelaskan Andi Mannappiang merupakan raja yang memimpin Bantaeng selama 2 kali masa jabatan yakni pada tahun 1939-1945 tetapi karena perjuangan melawan NICA maka Andi Mannappiang ditahan. Periode kedua tahun 1950-1952, setelah mengundurkan diri dari jabatannya beliau bekerja di Kantor Kejaksaan Tinggi Makassar sebagai hakim.
\end{abstract}

\section{Kata Kunci : Raja, Pejuang, Penegak Hukum}

\begin{abstract}
This study aims to describe Andi Mannappiang: King, Warrior and Law Enforcement (19051962) by revealing the background of Andi Mannappiang's life, education, and thought as a king, and Andi Mannappiang's gait and thought as a warrior and law enforcer. In this study shows that before Indonesian independence Bantaeng was under pressure from the Netherlands and Japan but after independence socio-political conditions in Bantaeng were very chaotic because of the arrival of the NICA and therefore formed an army of struggle to maintain the independence of the Republic of Indonesia in Bantaeng. Andi Mannappiang is a warrior who stirred up resistance in Bantaeng. In this study explains Andi Mannappiang is the king who led Bantaeng for 2 times a term of office in 1939-1945 but because of the struggle against NICA, Andi Mannappiang was arrested. The second period 1950-1952, after resigning from his position he worked in the Makassar High Prosecutors Office as a judge.
\end{abstract}

\section{Keywords : King, Warrior, Law Enforcement}

\section{A. Pendahuluan}

Kerajaan Bantayan dalam sejarah perkembangannya merupakan kerajaan yang mandiri. Namun setelah Kerajaan Gowa tampil sebagai pemegang supremasi di Jasirah Sulawesi Selatan, maka Bantaeng masuk menjadi wilayah kekuasaan Kerajaan
Gowa. Dalam literatur tidak terdapat catatan yang menyebutkan bahwa Kerajaan Bantaeng sebagai taklukan Kerajaan Gowa karena tidak pernah melakukan kontak senjata dengan Kerajaan Gowa. Selama melakukan ekspansi perluasan hegemoni, Kerajaan Bantaeng dijadikan sebagai salah 
satu lumbung pangan dan benteng pertahanan Kerajaan Gowa dari serangan Belanda yang berasal dari Maluku(Sahajuddin, 2016). Pada masa pemerintahan Belanda, Kerajaan Bantaeng dijadikan sebagai pusat pemerintahan bagian yang disebut pemerintahan Afdeling Bonthain sebagai bagian dari Hindia Belanda(Sahajuddin, 2016).

Andi Mannapiang lahir di Bantaeng pada tanggal 26 Februari 1905, pada masa kecil Andi Mannappiang hidup di lingkungan istana. Setelah umurnya cukup untuk mendapatkan pendidikan formal maka beliau di sekolahkan pada Sekolah Belanda yang disebut dengan Holland Inlandsehe School (HIS), sekolah ini didirikan di Bantaeng pada tahun 1912(Nastura, 2006).Pada awal karirnya Andi Mannappiang sebagai seorang terpelajar sekaligus sebagai seorang putra bangsawan yang amat dibutuhkan untuk dipekerjakan. Sebagai pegawai, Andi Mannappiang memilih bekerja sebagai seorang hakim di kehakiman Belanda.

Pada tahun 1939, Bantaeng dipimpin oleh Karaeng Andi Mannappiang. Dia menggantikan Karaeng Mangkala (19331938), bangsawan yang berpengaruh besar di Bantaeng. Andi Mannappaing dilantik pada bulan September tahun 1939. Dia diangkat sebagai Karaeng (Raja) Bantaeng oleh Adat Dua Belas (Adat sampulongrua).(Baso, 1995) sebagai karaeng karismatik, berpengaruh dan berwibawa. Maka Andi Mannappiang mampu menjadi panutan masyarakat dan sangat disegani semua lapisan, baik rakyat maupun oleh pemerintah atasannya(Nastura, 2006)

Secara garis besar bentuk perjuangan Andi Mannappiang dapat dibagi kedalam dua bentuk yakni bentuk fisik dan non fisik, dalam bentuk non fisik Andi Mannappiang memudahkan tokoh-tokoh menyebarkan propaganda-propaganda tentang anti penjajahan kepada masyarakat luas. Perjuangan Andi Mannappiang dimulai sejak zaman pendudukan Jepang, di Jakarta pemerintahan Jepang membentuk Panitia Persiapan Kemerdekaan Indonesia yaitu BPUPKI, sementara di Sulawesi Selatan Jepang membentuk organisasi yang disebut Sumber Darah Rakyat (SUDARA) yang dipimpin langsung oleh Andi Mannappiang dan berkembang pesat di daerah-daerah Afdeling.

Setelah menduduki jabatan sebagai ketua organisasi SUDARA, mempermudah langkah Andi Mannappiang untuk memperoleh informasi tentang persiapan dan perlawanan terhadap Jepang. Kekalahan pasukan Jepang akibat bom atom di Kota Nagasaki dan Hiroshima yang dijatuhkan oleh Amerika Serikat merupakan kesempatan bagi Indonesia untuk memproklamirkan kemerdekaan pada tanggal 17 Agustus 1945 proklamasi kemerdekaan dikumandangakan di Jakarta dan terdengar hingga di Bantaeng melalui radio yang dimiliki sebagian kecil masyarakat, seorang Tionghoa bernama Yau Tek dan Harsoyo. Andi Mannappiang mengkordinasi tiga organisasi perjuangan di daerah Bantaeng seperti SUDARA, Penerjang Penjajah Indonesia (PPI), Pemudah Merah Putih (PMP) namun mendapatkan tekanan yang keras dari pihak sekutu maka Andi Mannappiang mengubah menjadi Angkatan Muda Republik Indonesia (AMRI) dari wadah AMRI inilah perjuangan mulai bergerak kearah perjuangan fisik(Nastura, 2006). Pada tanggal 1 Mei 1950 Andi Mannappaing kembali di angkat menjadi Raja Bantaeng untuk yang kedua kalinya, pengangkatan ini didasari atas permintaan Hadat Dua Belas dan masyarakat khususnya hal ini didasarkan karena adanya ketidakpuasan Hadat Dua Belas dan masyarakat Bonthain terhadap raja yang memimpin masa itu.(Baso, 1995).

\section{B. Metode Penelitian}

Metode penelitian yang digunakan ialah kualitatif. Metode ini sering digunakan dalam ilmu sejarah dan ilmu sosial lainnya dengan tujuan untuk menemukan suatu hal yang unik dan mampu mengungkapkan 
peristiwa yang telah terjadi di masa lampau. (Priyadi, 2012)

\section{Heuristik}

Heuristik merupakan langkah awal dari metode penelitian sejarah, dimana pada tahap ini seorang peneliti mencari dan mengupayakan penemuan atas sumber sejarah yang memiliki keterkaitan dengan objek penelitian. Heuristik juga diartikan mencari dan mengumpulkan sumbersumber sejarah yang terkait dengan topik penelitian untuk mendapatkan sumber yang akurat. Dapat juga diartikan sebagai kegiatan penghimpunan jejak-jejak masa lampau, yakni peninggalan sejarah atau sumber apa saja yang dijadikan informasi dalam pengertian studi sejarah. (Sejarah, 2013). Dalam melakukan pengumpulan sumber, penulis menempuh dua cara:

\section{a. Penelitian Lapangan}

Kegiatan yang dilakukan dalam penelitian lapangan adalah mengadakan pegumpulan data secara langsung terhadap obyek yang menjadi sasaran penelitian. Dalam hal ini penulis menggunakan metode wawancara. Wawancara dilakukan kepada orang yang dianggap berkompeten dalam objek yang diteliti. Informan dalam penelitian ini yakni Andi Erni Trisansi Handayani dan Atte Sernilia Maladevi yang merupakan cucu dari Andi Mannappiang.

\section{b. Penelitian Pustaka}

Studi pustaka merupakan salah satu langkah penting dalam penelitian sejarah. Dalam studi pustaka ini dilakukan studi terhadap sejumlah bahan pustaka, baik yang berupa buku, dan hasil penelitian lainnya yang memiliki kaitan dengan topik penelitian. Penelitian pustaka dilakukan untuk menunjang penelitian lapangan.Referensi utama yang digunakan dalam penelitian ini adalah arsip yang yang dimiliki oleh Andi Erni Trisansi Handayani dan Inventaris Arsip Bantaeng (1866-1973). Penelitian pustaka dilakukan dengan mengumpulkan sumber berupa buku-buku, dokumen pemerintah setempat, hasil penelitian maupun artikel ilmiah yang berkaitan dengan hal-hal yang akan diteliti.

\section{Kritik}

Setelah mengumpulkan sumber maka langkah selanjutnya adalah menilai sumber tersebut untuk menyeleksi dan menguji kebenaran dan keabsahan suatu sumber, guna mendapatkan data yang otentik. Dalam kritik sumber, terdapat penekanan tertentu yang bertujuan untuk memberikan definisi kritik sumber itu sendiri. Tujuan dari kegiatan ini adalah bahwa setelah sejarawan berhasil mengumpulkan sumbersumber dalam penelitiannya, ia tidak akan menerima begitu saja apa yang tercantum dan tertulis pada sumber-sumber itu. (Sjamsuddin, 2012)

\section{Interpretasi}

Pada tahap ini dilakukan penafsiran terhadap data-data yang telah diseleksi. Kemampuan interpretasi adalah menguraikan fakta-fakta sejarah menurut data temuan karena tidak ada masa lalu dalam konteks sejarah yang sifatnya aktual sehingga harus ditafsirkan melalui data-data tersebut.(Sulasman, 2014)

\section{Historiografi}

Tahap ini merupakan tahap terakhir dalam metode penulisan sejarah yang digunakan oleh peneliti. Dalam tahap ini data-data yang tadinya telah ditafsirkan kemudian dirangkaikan menjadi sebuah tulisan untuk dapat mengungkapkan kisah sejarah yang diteliti secara kronologis yang menjadi objek kajiannya. Tentunya seorang penulis harus bisa menuangkan seluruh kemampuan daya pemikirannya, secara kritis dan analisa mendalam demi menciptakan tulisan sejarah yang mempunyai rentetan peristiwa yang terstruktur.

\section{Pembahasan}

1. Figur Andi Mannappiang

a. Latar Belakang Keluarga

Andi Mannappiang adalah keturunan langsung dari Raja Bantaeng yakni Karaeng Panawang Raja Bantaeng yang ke XXIV yakni memerintah sejak tahun 1877-1913, Karaeng Panawang beberapa kali beristri tercatat lebih 10 orang tetapi hanya beberapa orang yang memiliki keterunan 
yakni Saripa berasal dari Rumbia Jeneponto mempunyai tiga orang anak yakni Kr. Soreang, Kr. Pakenreng, Kr. Ati. Bunga berasal dari Panaikang Bantaeng mempunyai 8 orang anak yakni $\mathrm{Kr}$. Basauki, Kr. Ne', Kr. Kennang, Kr. Lakoma, Kr. Mangkala, Kr. Ru'bi, Kr. Maba, Kr. Banto. Mani’ berasal dari Tangnga-Tangnga Bantaeng memiliki seorang putri bernama Rantiga. Bollo berasal dari Makassar memiliki 2 orang putri bernama Buana dan Bunganna, dan istri terahir yakni Karaeng Mariama yang dilantik menjadi permaisuri yang diberi gelar Karaeng Bainea ri Bantaeng.

Karaeng Panawang menikah dengan Karaeng Mariama pada tanggal 31 Oktober 1897 dari pernikahannya inilah dikaruniai 2 orang anak, anak pertamanya seorang perempuan bernama Andi Bau' Dellung lahir pada tanggal 30 Juli 1898, dan anak yang kedua yakni Andi Mallappiang lahir pada tanggal 26 Februari 1905. Kemudian namanya berubah menjadi Andi Mannappiang sampai akhir hayatnya. Karaeng Panawang meninggal pada tahun 1922.

Pada masa kecil Andi Mannappiang hidup di lingkungan istana dan mendapatkan perhatian dari keluarganya. Beliau dididik oleh ibunya. Andi Mannappiang beberapa kali beristri dan beliau menikah pada usia yang sangat mudah yakni umur 16 tahun, istri pertama Andi Mannappiang yakni Isa Daeng Talle anak dari Karaeng Rimba dengan Andi Kangkong yang berasal dari Gowa dari pernikahaannya memperoleh seorang putri bernama Andi Bau' Monno. Pernikahan yang kedua dengan Mani' anak dari Karaeng Sinoa memilki seorang putri bernama Karaeng Dio. Pernikahan yang ketiga dengan Kama' Daeng Rannu yang berasal dari Makassar. Dari pernikahannya dengan Andi Mannappiang memperoleh beberapa orang anak tapi tidak ada yang hidup. Pernikahan yang keempat dengan Basaharia yang merupakan keluarga Kalia Bantaeng memiliki satu orang anak tetapi meninggal. Pernikahan yang kelima dengan
Datuloa yang berasal dari Sengkang ini tidak memperoleh keturunan. Pernikahan yang kelima dengan Andi Baiduri Karaeng Dampo yakni putri dari Karaeng Pawiloi yang merupakan sepupu dari Andi Mannappiang yang memiliki seorang putri bernama Andi Habibah.(Massualle, 1980). Kemudian, setahun setelah diangkat menjadi Raja Bantaeng oleh Adat Dua Belas dia menikah dengan Karaeng Basse anak dari Karaeng Djoppo dari Kampung Pasorongi Bantaeng yang kemudian diberi gelar Karaeng Bainea ri Bantaeng(Baso, 1995) dari pernikahan yang keeanam dengan Karaeng Basse dikaruniai dua orang anak yakni Andi Husaini dan Andi Alma Mariam.

Andi Mannappiang mangkat di Makassar pada tanggal 10 Desember 1962 pada usia 57 tahun dan dikuburkan berdampingan ayahnya Karaeng Panawang serta saudara saudaranya yang lain seperti Andi Mangkala, Karaeng Abdul Gani iparnya, Karaeng Maba dan Karaeng Pawiloy pamannya di pemakaman raja-raja Bantaeng di Bissampole yakni kompleks makam La Tenri Ruwa.

\section{b. Latar Belakang Pendidikan}

Andi Mannappiang merupakan putra kerajaan yang mengecap pendidikan Belanda yang tergolong langkah pada masyarakat kala itu. Pendidikan bagi anak raja atau putra putri bangsawan dilakukan oleh guru-guru yang sengaja didatangkan untuk itu nama guru ini dikenal dengan nama guru nandi, guru nandi ini mengajarkan tetang bagaimana tata cara bergaul secara sopan sesuai dengan pangngadakkang dan ajaran Islam. Sebagai seorang putra raja yang tingal di istana maka sebelum mendapatkan atau masuk pendidikan formal yang telah ada pada masa itu dalam hal ini sekolah HIS yang didirikan oleh Belanda, Andi Mannappiang telah dididik oleh keluarganya seperti halnya dengan anak-anak raja yang lain.

Setelah umur Andi Mannappiang layak dan cukup untuk mendapatkan pendidikan formal maka beliaupun disekolahkan di Holland Inlandsche School. Adapaun 
bahasa pengantar yang dipakai dalam sekolah HIS adalah bahasa Belanda dan dari sekolah HIS lah Andi Mannappiang mendapatkan keterampilan berbahasa Belanda yang baik sehingga mempermudah beliau bergaul dengan orang orang Belanda.(Massualle, 1980)

\section{Kiprah dan Pemikiran Andi Mannappiang Sebagai Pejuang dan Penegak Hukum}

\section{a. Perjuangan Andi Mannappiang Merintis Kemerdekaan}

1) Masa Pendudukan Jepang di Indonesia Perjuangan Andi Mannappiang membela bangsa dimulai sejak zaman pendudukan Jepang di Indonesia ketika ia diberikan kepercayaan selaku Kenrikan di Bantaeng dan membentuk SUDARA Cabang Bantaeng pada Juni 1945 dan memegang kedudukan tertinggi dalam organisasi tersebut, organisasi ini dimaksudkan untuk kerjasama kearah kemerdekaan.(Nastura, 2006)

\section{a) Proklamasi Kemerdekaan}

Teks proklamasi dibacakan oleh Soekarno Hatta atas nama Bangsa Indonesia di Pengangsan Timur Jakarta pada 17 Agustus 1945.(Nggengo, 1989).Sementara berita proklamasi kemerdekaan Indonesia barulah diketahui tokoh-tokoh politik yang ada di Bantaeng pada tanggal 19 Agustus 1945 oleh karena itu Andi Mannappiang secara rahasia memerintahkan A.M. Sidji Karim untuk memanggil Yau Yu Tek (seorang Tionghoa) bersama Harsoyo, Ince Ali Amir, Sugardo, Pujo Sumpeno untuk segera diantar ke rumah adat Bantaeng, setelah mereka sampai ke rumah adat Bantaeng maka Yau Yu Tek menjelaskan bahwa ia telah mendengarkan di radio Jawa Hooso Kyoku bahwa di Jakarta pada tanggal 17 Agustus 1945 Soekarno Hatta telah mengumumkan kemerdekaan Indonesia.(Nastura, 2006)

b) Perjuangan Andi Mannappiang Mempertahankan Kemerdekaan

(1) Kedatangan NICA di Indonesia

Sekutu tiba di Indonesia pada September 1945. Pasukan AIF Brigade
XXI yang berada di bawah pimpinan Brig. Jenderal Iwan Dougherty mendarat di Makassar pada 21 September 1945(Amir, 2014). Diantara pasukan Australia itu, terdapat pula aparat-aparat NICA dibawah pimpinan Mayor J.G. Wegner. Bahkan sebagian besar pasukan yang mendarat itu adalah aparat NICA(Amir, 2014)

\section{(a) Awal Terbentuknya Laskar Perjuangan di Bantaeng}

Di daerah-daerah Sulawesi Selatan para pemuda membentuk organisasi guna menggalang gerakan mereka. Sedangkan yang dibentuk di daerah-daerah pada umumnya secara terbuka misalnya di Luwu, Mandar, Bantaeng, Polongbangkeng, Jeneponto, Pare-Pare dan ditempat yang mendapat dukungan dari rajanya. Karena dengan ikutnya raja berjuang maka dengan sendirinya rakyat akan ikut kepada rajanya karena raja memegang peranan penting dan sangat berpengaruh pada masa itu. Di Bantaeng Andi Mannappiang dengan tegas menyatakan berdiri dibelakang Republik Indonesia secara tidak langsung rakyat mendengarkan pernyataan rajanya dan siap bertempur untuk mempertahankan kemerdekaan. Oleh karana itu dibentuklah organisasi perjuangan di Bantaeng untuk mempertahankan kemerdekaan.

\section{(b) Organisasi Pemuda Merah Putih (PMP)}

Setelah proklamasi kemerdekaan Republik Indonesia tanggal 17 Agustus 1945 gubernur Sulawesi Dr. Sam Ratulangi mengirim utusan ke daerah- daerah untuk membentuk organisasi untuk mempertahankan kemerdekaan. Utusan kedaerah Bantaeng yakni Lanto Daeng Pasewang, Najamuddian Daeng Malewa, Malajong Daeng Liwang, Mr. Tajuddin Noer, Manai Sophian, Massiara, Muh. Risa.(Jumadi, 1968)Pada tanggal 20 Agustus 1945 akhirnya dibuat suatu pertemuan dengan utusan Gubernur Sulawesi di Kantor Karaeng Bantaeng untuk membentuk barisan Pemuda Merah Putih (PMP) dalam pertemuan itu Andi Mannapiang memimpin langsung pertemuan dan dibantu oleh staf Kantor 
Karaeng Bantaeng Qaimuddin Jumadi dan Baso Gani. Adapun yang hadir pada waktu itu adalah: Andi Mannappiang (Karaeng Bantaeng), Abdul Salam, Mustafa Tari, Abd Rasyid Faqih, Qaimuddin Jumadi, Abdullah Baso, Abd. Wahid Kaluku, Husai Kr. Opu, Jumadi P, S. Majid, Tanawali, Kr. Joppo, Kr. Wahid, Loko Dg Tompo, Abdullah, H. Samudo, Siji Karim, H. Patola, H. Ambo Daeng, Muridong, Pabbottingi, Rustam, Abdul Kadir, Baso Gani, Ahmad Munassar, Muharram, Tappi Dg. Rate, Abdul Razak, Muh. Siala, Mahmud, Kepala Kampung (Anrong Tau), Masyarakat Bantaeng.

Pada tanggal 7 September 1945 atas persetujuan pemerintah Republik Indonesia di Bantaeng dalam rapatnya bersama pemuda-pemuda dengan Andi Mannappiang maka diputuskan untuk membentuk wadah perjuangan dengan nama Pemuda Merah Putih (PMP) untuk mempertahankan NKRI. Pembentukan PMP merupakan wadah perjuangan yang mendukung proklamasi kemerdekaan Indonesia. Dalam pembentukannya, tokubetsu booei teisin tai menjadi inti gerakan ini dan diperkuat oleh bekas heiho. Adapun susunan PMP:
1. Pemimpin
Tertinggi:Andi

Mannappiang (Karaeng Bantaeng)

2. Pimpinann Harian:Abdul Salam (Tuan Guru Salam)

3. Wakil Pemimpin Harian:Abdul Wahid Kaluku

4. Pemipmpin Staf: Qaimuddin Jumadi

5. Wakil Pemimpin Staf: Abdullah Baso

6. Anggota Staf PM: Abdul jalil, Abdul Razak, dan Bakri

Pimpinan pemuda dan daerah tugas

1. Pusat Kota Bantaeng:Abdullah Baso

2. Bagian Barat Kota Bantaeng: Daeng Nyallu

3. Bagian Utara Kota Bantaenng : Muharram

4. Bagian Timur Kota Bantaeng: Muh. Siala dan Abd. Karim Bella

5. Bagian Pesisir Kota Bantaeng: Pabottingi
6. Banyorang dan sekitarnya :Abdul

Kadir, Abdul Wahab,Lawing, Ahmad karim

7. Pembantu Anggota Fujikai:Siti Hasna, Rajawang, Siti Hafsa dll.(Jumadi, 1968)

Organisasi Merah Putih hanya berusia dua bulan dan kemudaian diganti menjadi Angkatan Muda Republik Indonesia hal ini dikarenakan PMP mendapatkan tekanan dari pihak sekutu. Perubahan nama ini untuk mengkordinir gerakan yang ada di Bantaeng. (Nastura, 2006)

(c) Angkatan Muda Republik Indonesia (AMRI)

Pemuda Merah Puth (PMP) merupakan cikal bakal dari terbentuknya AMRI yang dibentuk pada bulan November 1945. Yang dimana susunan organisasi ini masih sama dengan organisasi sebelumnya (PMP). Andi Mannappiang sebagai pemimpin tertinggi begitupun dengan stafnnya tidak ada yang mengalami perubahan.(Nastura, 2006). Hal ini disebabkan karena memandang perlu untuk membentuk formasi serta wadah perjuangan yang berbentuk kelaskaran bersenjata di daerah Bantaeng guna untuk menghadapi musuh Bangsa Indonesia di Bantaeng dalam hal ini adalah NICA yang ingin mengambil alih dan menguasai Indonesia sebagai bangsa yang telah merdeka. Dari wadah AMRI inilah bentuk perjuangan mulai berubah dari nonfisik ke perlawanan fisik.

(d) Tertangkapnya Andi Mannapiang

Pada tanggal 20 November 1945 Andi Mannappiang dibawa ke Makassar oleh tentara NICA dan ditahan dengan tuduhan suatu perkara politik di Banteang.(Baso, 1995).

Adapun organisasi kelaskaran yang dibentuk setelah AMRI untuk mempertahankan kemerdekaan antara lain: (e) Penerjang Penjajah Indonesia (PPI)

Penerjang Penjajah Indonesia (PPI) merupakan kelaskaran yang dibentuk oleh Abdul Rasyid Faqih pada 17 Oktober 1945 yang dimana daerah perjuangannya meliputi Bonthain, Kassi (Binamu), Malakaji dan Bulukumba. Kelaskaran ini 
pada mulanya bermarkas di Bantaeng dengan tujuan untuk membela dan mempertahankan kemerdekaan Republik Indonesia serta membela proklamasi 17 Agustus 1945. Pada tahun 1946 melalui perundingan selama 2 hari berturut turut maka PPI diterima oleh pimpinan LAPRIS yakni Ranggong Dg Romo bergabung menjadi anggota LAPRIS dengan tugas pertanggungjawaban di Daerah Bonthain.(Saransi, 2007)

(f) KRIS Muda Cabang Bantaeng yang dipimpin oleh abdul Wahid Kaluku.

Memuncaknya perlawanan terhadap NICA yang dilaksanakan dimana-mana maka bertambah pula aksi-aksi westerling, oleh karena itu diadakan pula penangkapan besar-besaran bagi pejuang kemerdekaan yang ada di Bantaeng karena Belanda telah mengetahui adanya organisasi KRIS Muda di Bantaeng, sehingga dalam operasi itu tertangkap Abdul Wahid, Mustafa Tari Husain, K.M. Doenggio, Abdullah Baso, Soeharto, Qaimuddin Jumadi, H. Pattolah, Abd Karim Dullah karena mereka sebagian besar pemimpin KRIS Muda cabang Bantaeng.(Jumadi, 1968)

\section{(g) Perjuangan Andi Mannappiang Menegakkan Hukum dan Keadilan}

Setelah Andi Mannapiang memundurkan diri sebagai karaengdi Bantaeng pada tanggal 1 Juni 1962, saat itu pulalah Andi Mannapiang berkeinginan untuk bekerja di bidang lain, yaitu di kantor kejaksaan tinggi Makassar sebagai hakim.Andi Mannapiang bekerja sebagai hakim di kejaksaan tinggi Makassar tidak begitu lama, karena mengingat usianya yang sudah lanjut dan kesehatannya sudah tidak memungkinkan lagi untuk bekerja. Pada saat itu pulalah Andi Mannapiang di berhentikan bekerja sebagai hakim dikejaksaan tinggi Makassar.(Baso, 1995)

Andi Mannappiang meninggal pada tanggal 10 Desember 1962 di Makassar dan jenazahnya dimakamkan di Bantaeng. Selama menjadi karaeng di Bantaeng sampai akhir hayatnya beliau didampingi oleh istrinya Karaeng Basse. Semasa hidupnya Andi Mannapppiang dikenal dengan sifatnya yang tidak sombong, menolong sesama manusia, bergaul dengan rakyat dan selama menjadi Karaeng Bantaeng tidak pernah didengar memukul rakyat, suka berkelakar dan sangat menghormati tamunya. Ketegasan dan keberaniannya adalah karakter yang sangat menonjol dari beliau, banyak dari kalangan pejabat Belanda yang memberinya gelar sebagai raja cerdas di Bantaeng, namun sungguh julukan itu tak membuatnya menjadi pribadi yang angkuh.(Massualle, 1980)

\section{E. Kesimpulan}

Berdasarkan uraian pembahasan yang telah dipaparkan pada halaman sebelumnya, maka dapat ditarik kesimpulan sebagai berikut:

Andi Mannappiang lahir pada tanggal 26 Februari 1905. beliau menikah pada usia yang sangat mudah yakni umur 16 tahun. Pada tahun 1939 beliau diangkat menjadi Raja Bantaeng. Setahun setelah diangkat menjadi Raja Bantaeng oleh Adat Dua Belas dia menikah dengan Karaeng Basse anak dari Karaeng Djoppo dari Kampung Pasorongi Bantaeng yang kemudian diberi gelar Karaeng Bainea ri Bantaeng

Andi Mannappiang merupakan putra kerajaan yang mengecap pendidikan Belanda yang tergolong langkah pada masyarakat kala itu yakni di Holland Inlandsche School (HIS).

Perjuangan Andi Mannappiang membela bangsa dimulai sejak zaman pendudukan Jepang di Indonesia. Ketika itu, diberikan kepercayaan selaku Kenrikan di Bantaeng dan membentuk Organisasi Sumber Darah Rakyat (SUDARA) Cabang Bantaeng pada juni 1945. Setelah Indonesia merdeka, dibentuklah organisasi perjuangan di Bantaeng untuk mempertahankan kemerdekaan. Antara lain Pemuda Merah Putih (PMP) pada tanggal 7 September 1945. Namun organisasi Merah Putih hanya berusia dua bulan dan kemudaian diganti menjadi Angkatan Muda Republik (AMRI) 
Indonesia. dari wadah AMRI inilah bentuk perjuangan mulai berubah dari nonfisik ke perlawanan fisik. Bentrokan yang terjadi antara aparat NICA di Bantaeng menyebabkan Andi Mannappiang tertangkap.

\section{DAFTAR PUSTAKA}

Amir, M., 2014. Perjuangan Hammad Saleh Menentang Jepang dan Belanda di Mandar 1942-1947. Makassar: Arus Timur.

Baso, M. N., 1995. Inventaris Arsip Bantaeng (1866-1973) no Reg 16, Surat/nota De hulp Bestuurs Assistant Resident Bonthain mengenai masalah kegiatan pemerintah di daerah Afdeeling Bonthain., Ujung Pandang: Badan Arsip dan Perpustakaan Daerah Propinsi Sulawesi Selatan.

Baso, M. N., 1995. Inventaris Arsip Bantaeng (1866-1973) no Reg 66 Berkas Pengangkatan Karaeng Bonthain Andi Mannappiang dan Karaeng Pawiloi, Ujung Pandang: Badan Arsip dan Perpustakaan Daerah Provinsi Sulawesi Selatan.

Baso, M. N., 1995. Inventaris Arsip Bantaeng (1866-1973) No. Reg. 16, Surat/nota De hulp Bestuurs Assistant Resident Bonthain mengenai masalah kegiatan pemerintah di daerah Afdeeling Bonthain., Ujung Pandang: Badan Arsip dan Perpustakaan Daerah Propinsi Sulawesi Selatan.

Baso, M. N., 1995. Inventaris Arsip Bantaeng (1866-1973), No. Reg. 66, Berkas pengangkatan Karaeng Bonthain Andi Mannappiang dan Karaeng Pawiloi., Ujung Pandang: Badan Arsip dan Perpustakaan Daerah Provinsi Sulawesi Selatan.

Baso, M. N., 1995. Inventaris Arsip Bontahin No.Reg. 178, tentang berkas pengangkatan Andi Mannapiang sebaga Karaeng/Kepala Wanua Bonthain
(1950-1953)., Ujung Pamdang: Badan Arsip dan Perpustakaan Daerah Provinsi Sulawesi Selatan.

Jumadi, Q., 1968. Kutipan Catatan Barisan Pemuda Kelaskaran di Bantaen. s.l.:s.n.

Massualle, A., 1980. Ringkasan Riwayat Andi Mannappiang, s.l.: s.n.

Nastura, N., 2006. Bantaeng Biografi 35 Tokoh-Tokoh Bantaeng. s.l.:Kantor Kebudayaan dan Pariwisata Kabupaten.

Nggengo, O., 1989. Ratulangi Profil Intelektual dalam Perjuangan Kemerdekaan Indonesia, Makassar: Fakultas Sastra Universitas Hasanuddin.

Priyadi, S., 2012. Metode Penelitian Pendidikan Sejarah. Yogyakarta: Ombak.

Sahajuddin, 2016. Konflik Kepentingan di Kerajaan Bantaeng pada Abad ke XVII. Pangaderreng, p. 281.

Saransi, A. A., 2007. Inventaris Arsip Statis Legium Veteran Republik Indonesia Tahun 1931-1985, No Reg: 191 Naskah Rangkaian Sejarah Kelaskaran Tahun 1945-1949., Makassar: Badan Arsip dan Perpustakaan Daerah Provinsi Sulawesi Selatan.

Sejarah, T. P. J. P., 2013. pengantar Ilmu Sejarah, Makassar: Balai Penerbit UNM.

Sulasman, 2014. Metodologi Penelitian Sejarah, Teori, Metode, Contoh Aplikasi. Bandung: Pustaka Setia. 